\title{
Chapter 4. Banua or Negara? The Culture of Land in South Bali
}

\section{Graeme MacRae}

Land has always been a critical resource in the successive political economies of south Bali, and not surprisingly, it has also been deeply embedded in a rich matrix of cultural meanings. 1 This, was evident to the earliest foreign observers - 'There is a ... correlation of the ... people with ... the land' (Covarrubias 1994: 11, see also pp. 59, 84) - and has remained so until relatively recently. In the past generation, however, land has been relocated substantially from this matrix of meaning into something increasingly resembling the universal capitalist commodity hidden in the misleading term 'real estate', with all the attendant emptying-out of traditional meaning. This has happened primarily through its massive revaluation and inflation as a primary resource in an economy dominated by tourism as well as systematic attempts by the National Government, aided and abetted by foreign agencies, to 'free' it from the bonds of traditional forms of tenure and make it available to the widest possible market.

This process has been further aided at a more subtle psycho-cultural level by the phenomenological effects of various technologies that have progressively diluted and obscured the once-powerful and awe-inspiring daily (and particularly nightly) experience of landscape. Roads have connected places, such as the mountains or distant kingdoms, once awesome for their sheer remoteness. Motor vehicles have reduced distances of days to a matter of hours and their omnipresent noise, smell and sheer mechanical power have annulled much of the direct sensory experience of landscape, which was integral to the knowledge of previous generations. Kerosene lamps, battery-powered torches and more recently electric lighting penetrate the veil of darkness that once obscured the sekala (natural world), allowing people to glimpse the niskala (supernatural world) beyond. Radio, television and electronic amplification have pushed aside the sounds of bamboo rustling in the wind, the fading notes of a distant gamelan or even the stately creak of an ancient Dutch bicycle. People born since about 1970 have little or no experience of the landscape unmediated by these technologies, and when I ask them for directions they reply in terms of gas stations and hotels rather than waringin trees or temples.

I have discussed elsewhere some political-economic aspects of land in south Bali (MacRae 2003). The purpose of this chapter is to consider the matrix of meaning and customary practices in which land was and to some extent still is embedded. As with the political-economic dimension, from which they can never be entirely separated, these occur in the context of concrete historical processes. 
The land has always been there, a primary element of human experience, and successive cultural and political orders have made their own sense and inscribed their own meanings on it. Some recent transformations of these have been touched on above, but the primary axis around which this discussion revolves is the extent to which 'traditional' ideas and practices to do with land might usefully be seen in terms of ancient, pre-Indic forms, common to a degree throughout the Austronesian world and evident especially in the Bali Aga forms described by Reuter (this volume).

\section{The Cultural Landscape of South Bali}

The south-central quarter of Bali is a wedge of land, sloping down and out from the central mountains, steeply at first, then flattening onto a coastal plain several kilometres wide. The soil is predominantly volcanic ash (paras), fertile and soft, allowing the rivers flowing down from the mountains to cut deep gorges, dividing the land into long tapering radial strips. In these gorges are remnants of the original rainforest that once covered most of the island while the strips between, some little more than ridges, others relatively flat and a kilometre or more wide, are terraced, irrigated and planted with rice and secondary crops such as sweet potato, interspersed with rows of coconut palms.

This landscape is divided, in traditional Balinese thinking, into two primary categories: wild forest (alas or [BI] hutan) and land that has been brought into human cultivation and ritual order (Boon 1977: 99). ${ }^{2}$ Alas is inhabited by all manner of unseen (niskala) beings that are potentially disruptive and even dangerous to human life. When it is occupied by humans, the forest is cut, social and spatial institutions are established and ritual processes initiated to maintain harmony between human and niskala inhabitants. ${ }^{3}$

A well-known origin story in this part of Bali concerns Rsi Markandeya, a holy man from East Java, who came, with followers, to establish a community in the wilderness of Bali. They began cutting (marabas) forest by the River Wos at Campuan near Ubud, but were attacked by wild animals and diseases and the expedition was abandoned. Back in Java, Markandeya, received supernatural advice that he had neglected to establish the proper ritual relationships with the niskala inhabitants of the place. He tried again, this time taking appropriate ritual precautions, the most important of which was the burial of five elemental metals (panca datu) in the soil of the new land. This time he was to be rewarded with success. They cleared the forest, divided the land into dry and irrigated fields and established the primary institutions of social, ritual and economic organisation-banjar, desa and subak. ${ }^{4}$ Banjar is the local community organisation oriented to essential social tasks, especially the disposal of the dead. Subak is the organisation responsible for the collective management of irrigation water, essential to material subsistence. Desa is the organisation responsible for 
the maintenance of ritual harmony between human and niskala communities in a particular spatial/ecological zone. ${ }^{5}$

While it can be argued that banjar is the primary secular social unit (Guermonprez 1991), desa is the primary spatial and ritual unit (commonly, but somewhat misleadingly, translated as 'village') - binding local community to local landscape through collective responsibility to local deities. ${ }^{6}$ Land is understood to belong to these deities. Humans occupy and use it on what may be described as a leasehold basis, perpetual but subject to the regular performance of collective ritual obligations. It is the desa, rather than individuals, which is party to this arrangement with the gods, and individual households maintain their right to occupy desa land (tanah ayahan desa) by contributing to collective ritual obligations (Boon 1977: 100-2; Covarrubias 1994: 59,84; Reuter 2002b; Stuart-Fox 2002: 42-4; Warren 1993: 38-42). These obligations take the primary form of maintaining two (or more) main temples and performing in them regular ceremonies, which the various deities associated with the desa are invited to visit and are then plied with offerings of music, dance, food, flowers, incense and sacrificial animals.

The two main temples are the pura puseh ('navel', 'centre' or 'origin' temple) and the pura dalem (temple of the 'great deity' of death). The pura puseh is associated with the origins of the desa, in the form of founding ancestors and life-giving water from the mountains, and is located ideally and usually towards the uphill (kaja) end of the desa territory. It usually contains, in its middle courtyard (jaba tengah), a pavilion known as bale agung (great pavilion), in which all the gods of the desa assemble periodically. The pura dalem is associated with the spirits of the dead, but not yet fully purified and deified members of the desa. It is located ideally and usually near the graveyard and cremation ground (setra) at the downhill (kelod) end of the desa territory. ${ }^{7}$

The walled compounds (pekarangan) occupied by households of the desa are strung along either side of the uphill-downhill road (and sometimes parallel secondary streets) between these two temples. Each house yard is occupied by a household (or set of related households) in perpetuity but subject to prescribed contributions to collective ritual (ayahan, literally 'work'). Such land (pekarangan desa or karang ayahan desa) might not be bought or sold. ${ }^{8}$ Spatially, each house yard replicates the fundamental uphill-downhill orientation of the desa itself. ${ }^{9}$ Desa are bounded laterally (east-west in this part of Bali) by the untamed space of the parallel river gorges and in the uphill-downhill direction by a neutral zone of cultivated land, which is owned by individuals and managed by subak. 


\section{Figure 1: Typical Desa layouts}

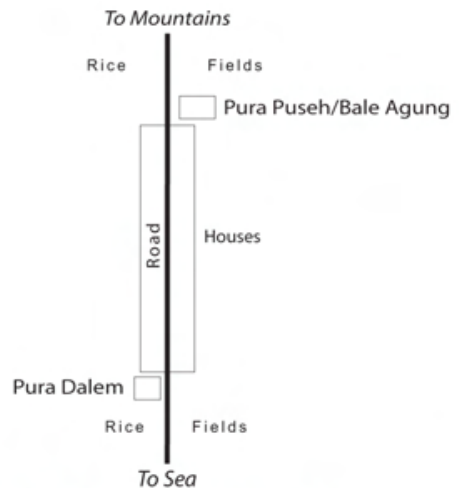

DESA TANGAYUDA

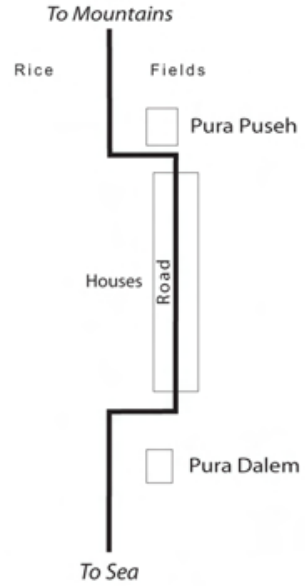

DESA TANGKUP

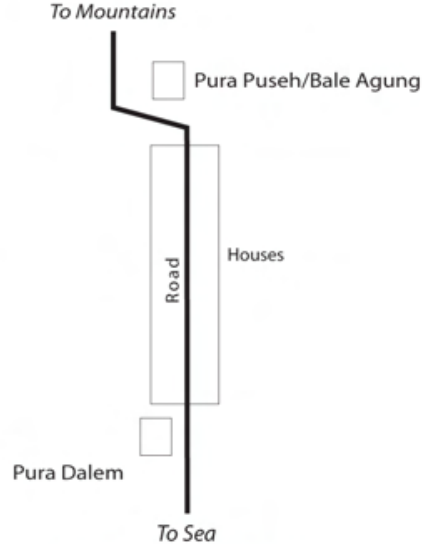

DESA BONJAKA

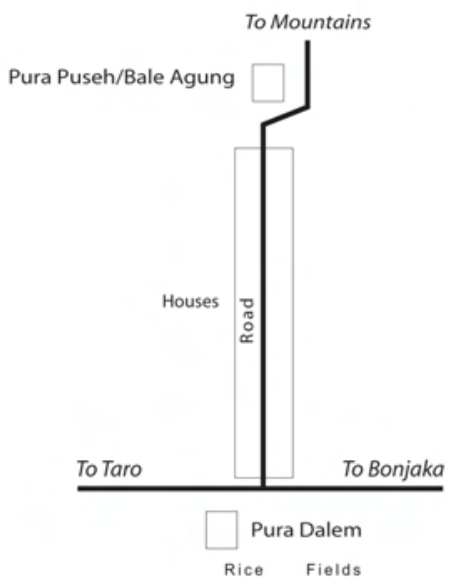

DESA BELONG $100 \mathrm{~m}$

\section{Land Tenure}

While household land is held in trust by the desa, articulating the ritual-economic relationship between humans and gods, there are also other kinds of collectively held land. Laba pura is productive land reserved for the material support of particular temples. Many desa and temples also have land (tanah bukti) reserved for the support of desa officials (klian, bendesa) or temple priests (pemangku). Streets, pathways and other public spaces including setra are collective property and are maintained by banjar, as are local community halls (bale banjar). 
Productive land, on the other hand, is generally privately owned, a right established initially by clearing and cultivation, later by capture and redistribution by local rulers and currently by sale and purchase.

Across this mosaic of desa and agricultural land are overlaid the historical designs and ambitions of a series of ruling elites, many of them descended from noble warriors of the Hindu-Javanese empire of Majapahit whose forces invaded Bali in the 14th century. They brought with them more hierarchical modes of social and political organization, which were also inscribed onto the landscape. A proportion of desa in this part of Bali thus have, superimposed on the linear/axial spatial organisation described above, a centric, mandala form, focused on a central crossroads, where rulers built puri (palaces), markets and temples. In most of these desa, the bale agung has been relocated to a pura desa in this central complex. 10

As well as appropriating and reconfiguring the ritual (or niskala) landscape of desa, new or invading puri took control of substantial areas of productive land, which they allowed their subject populations to continue to cultivate through various arrangements. The most distinctive and widely used in this part of Bali was a system known as pecatu or tanah ayahan puri, by which land was made available to farmers for their subsistence in exchange not for a portion of the crop but for certain services to the puri. The nature of pecatu has been the subject of considerable debate since the attempts of the first Dutch administrators to make sense of it (Gunning and van der Heiden 1926; de Kat Angelino 1921). The debate essentially concerns the extent to which it was a system of forced labour, of patronage or a variation on traditional desa obligations (Boon 1977: 56; Geertz 1980: 176; Hobart et al 1996: 55; Schulte-Nordholt 1996: 60; Warren 1993: 63). It is my impression that the divergence of interpretations probably reflects as much local differences of practice and terminology as it does the relative correctness of the authors. What is significant here is that it is a system in which rights to productive land are exchanged for labour obligations. As a result, just as residential land was occupied subject to ritual obligations to the gods via the desa, use of much productive land became increasingly subject to corresponding obligations to puri. ${ }^{11}$

\section{Trans-local Organisation}

It is unclear what, if any forms of socio-spatial organisation larger than desa existed in this part of Bali before or independent of the multiplication and expansion of puri in the 18th century. On the one hand it is reasonable to expect that 'ritual domains' along the lines of the Bali Aga banua described by Reuter (this volume) might have existed, but on the other, the evidence of local oral history suggests that the settlement of much of the area coincided with rather than predated puri expansion. 
The anthropological record is also somewhat ambiguous on this subject. While the Dutch scholarly colonial orthodoxy that 'the village forms a closed, self-contained unit' (Goris 1984: 79) has long since fallen from favour, subsequent writers continued to take for granted the village as the natural unit of analysis. ${ }^{12}$ This focus has been at the expense of recognising modes of organisation beyond and between villages. The existence of such modes of organisation is, however, evident in the literature. This evidence includes:

1. Seasonal migrations of barong and performing art troupes between villages and/or temples (Lansing 1983; Mead 1970).

2. The formation of links between villages through temples (Bateson 1970; Boon 1977: 100).

3. Groups of 'mother-daughter' villages in East Karangasem and Batur-Kintamani areas (Boon 1997: 104-5; Covarrubias 1994: 58, Goris 1969: 107-8, 1984: 96, Stuart-Fox 2002: 49-51).

4. Royal patronage of local temples and systems of 'state temples' at central, uphill and seaward extremities of kingdoms.

5. The travels of Rsi Markandeya (Howe 1980: 13, Stuart-Fox 2002: 261-3) or other mytho-historical connections (Boon 1977: 100).

6. Market networks (Hobart 1979: 69-74).

Despite such widespread evidence, the implications have not been pursued systematically with the exceptions of Lansing's (1991) work on water temples, Schulte-Nordholt's (1988a, 1991a,1991b) on pre-colonial state temples, and Reuter's (1998, 2002a) more recent work on Bali Aga banua. None of these refer to the ordinary villages and temples of south Bali. Recent ethnographic evidence, however, indicates traces of banua-like forms, especially the further one moves uphill from the puri centres of Ubud, Tegallalang and Payangan, towards the more unequivocally Bali Aga areas documented by Reuter. ${ }^{13}$

For example, Desa Sebatu, according to local tradition never subject to puri control, is the centre of a network of some five desa linked by reciprocal ritual ties. They are not, however, referred to as a named collective entity. The ritual cycle in these desa is, as in mountain banua, tied to the old lunar calendar (sasih) rather than the Hindu-Javanese one (wuku). On the other hand, they utilise the services of Brahman high priests (pendeta) in some of their rituals, which is evidence of influence from the Majapahit lowlands.

In nearby Pujung (Talepud), Leo Howe (1980: 13-27) reports a similar blend of lowland and highland customs, as well as local oral traditions including a version of the Rsi Markandeya story, which link Talepud to nearby desa. Unfortunately, he gives little detail of contemporary practices of trans-desa organisation. According to my inquiries in Pujung in 1996, however, it is the centre of a group of nine ritually linked desa but these are not referred to as a banua. Pendeta do not officiate at temple rituals here and the ritual cycle is tied 
neither to the lunar nor wuku calendars, but to the local cycle of the traditional rice crop. The form and seating arrangements of desa meetings likewise appear to be a fusion of elements characteristic of mountain and lowland forms. Local opinion, however, sees it more as the transplantation of the forms of their village of origin in Karangasem (East Bali), forms that are themselves more consistent with those Reuter characterises as Bali Aga.

Immediately downhill of Pujung and Sebatu are a number of small desa (e.g, Kebon, Tangkup, Cebok), which have no bale agung of their own but share that of the older village from which they originated (e.g, Kedisan)-a mode of relationship consistent with processes of linkage in both the mountains and East Bali (Reuter 2002: 38-41; Stuart-Fox 2002: 46-51). At roughly the same elevation and a couple of ridge/valley systems to the west, near Payangan, is yet another group of eight desa, linked to a shared temple, known as Pura Banua, in Desa Bukian. Unlike the category of Bali Aga temples of the same name (pura banua), this Pura Banua is not understood as the centre of a ritual domain so much as a regional temple with a unique history. According to local oral narratives, its origin lies not in a ritual alliance but a defensive one, at the time of the Payangan wars of 1843, with the temple being a place of assembly in times of crisis. However, the term and metaphor of banua was chosen, which suggests familiarity with the concept, and, as Reuter (2002: 80) notes, this area is one of the few puri-dominated areas with strong ritual links to Bali Aga temples. ${ }^{14}$

The evidence of all of these examples consists merely of traces of various kinds, and there is no evidence of systematic organisation or a sense of collective identity as in the mountain banua. David Stuart-Fox (2002: 46-51), writing of similar but different groupings of villages further east in Bali, reminds us, however, that no matter how ancient and timeless they may appear, all these groupings of villages are the result of concrete historical processes. I would suggest furthermore that it is to these processes that we need look if we are to understand their contemporary forms; a point to which we will return later.

If we look further downhill, where the political and ritual dominance of puri increases there is progressively less evidence of such forms or of 'ritual domains' (banua) other than pre-colonial 'kingdoms' (negara). This would suggest that banua are either a form distinctive to the mountain regions for some reason, or that they have been eliminated or obscured in the areas subject to Majapahit puri domination. There remains, however, the evidence listed above, even in relatively downhill areas, of elements of inter-desa organisation, articulated through links between temples. Are they negara or banua or something else? The remainder of this paper considers this question by summarising and examining my own ethnographic evidence of a more substantial network of linkages in the upper Wos Valley. 


\section{The 'Ritual Domain' of the Wos Valley}

Village temples ... are linked together in a given area by hereditary ties or because of allegiance to a princely house or to that of a Brahmana high priest. Thus to the head temple on the day of its yearly festival will come the members and the priests from a number of tributary temples round about, bearing their gods in procession, accompanied by their gamelan orchestras, with spears and banners and all ceremonial regalia, and bringing also the Barong and the Rangda. (Jane Belo 1949: 40)

At Campuan, in the gorge just west of Ubud, above a fork in the River Wos, is the temple Pura Gunung Lebah. The name means literally 'low mountain', 'below the mountain' or 'the mountain below'. It is held in local lore to be especially sacred but it does not fit unambiguously into the conventional scheme of local temples. It is specific neither to desa nor to any one clearly defined group. The ayahan is performed by a group of subak around Ubud and the people of Banjar Taman Kelod, working on behalf of Puri Ubud. 15 Its major palingih (sitting-places for visiting deities) are two pagoda-like towers (meru) - a seven-tiered one for the resident deity of Gunung Lebah and a five-tiered one for Bhatari Sri Batur (the goddess of Mt/Lake Batur).

At the beginning of anniversary ceremonies (odalan), processions arrive from Ubud and from a circle of villages approximately centred on the temple. These people bring their barong (gods in the form of large animal puppets) and other sacred objects, most of which were made, donated by, or in some other way connected to the puri. In explaining their relationship with the temple, they refer to these connections and also to Rsi Markandeya and his travel up the Wos Valley.

Pura Gunung Lebah has a range of associations and meanings, constituted in different ways. It is (a) the pura masceti (regional irrigation temple) for a group of subak, (b) a royal temple of the puri, and is associated (c) with a group of villages, including Ubud, and their barong, (d) with the travels of Rsi Markandeya, (e) with the Wos Valley as far as Taro, and is finally (f) a visiting place (pasimpangan) for the goddess of Mt/Lake Batur. These connections are articulated through the temple but are not organised around a single consistent set of ideas. They are constituted variously through more or less defined groups of people, through the static form of land and the dynamic of flowing water and through hazily remembered mythologies and the regular visits of gods. ${ }^{16}$ 
Figure 2: The Pura Gunung Lebah network

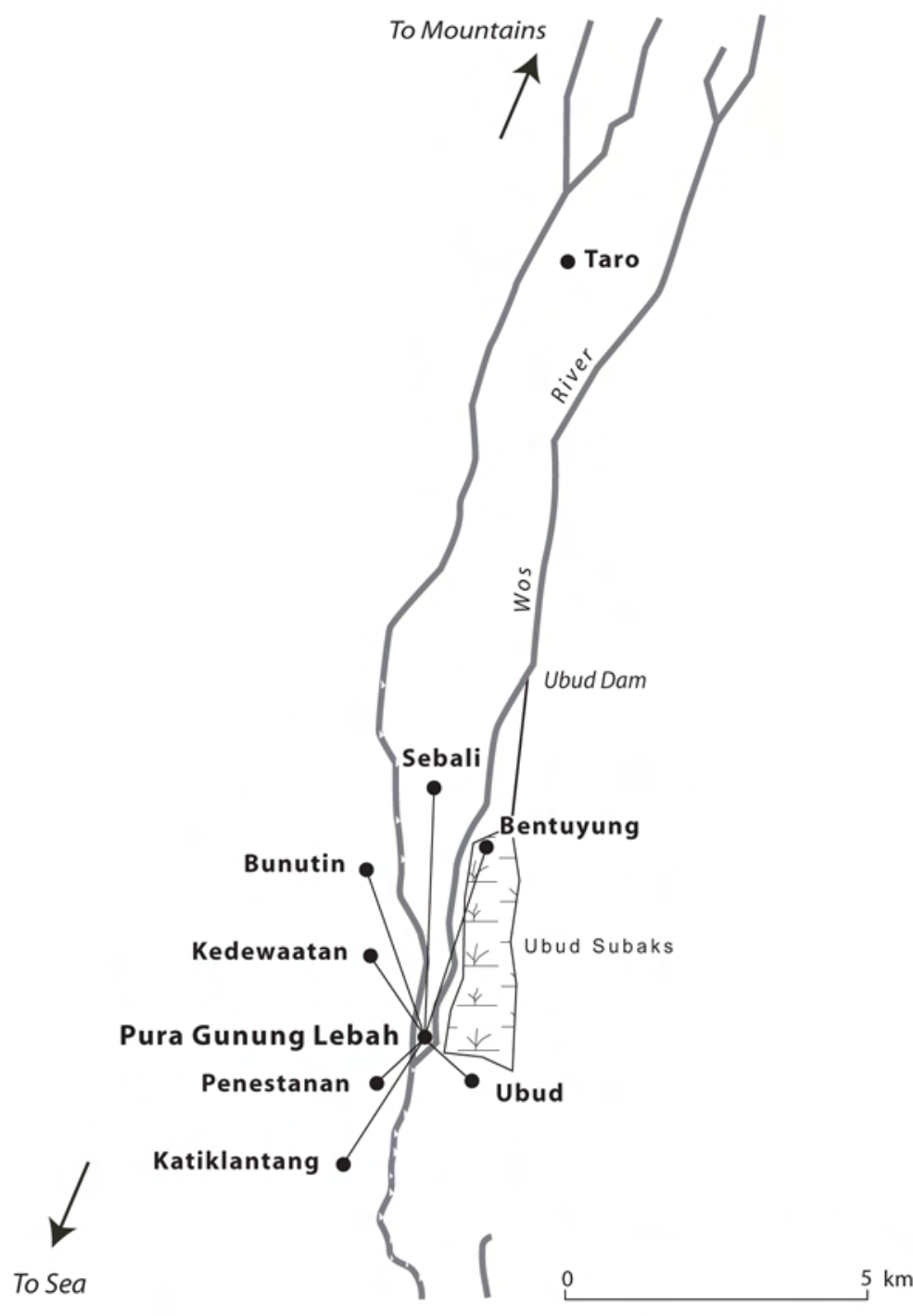

Many of the desa connected to Pura Gunung Lebah are themselves linked in similar ways to others around Ubud and eventually to others all the way up the Wos Valley. The net result of these linkages may be described as a network of villages and temples within a more or less defined region. This network takes the form not of a single grid but of several imperfectly overlapping ones constituted variously in the dimensions of topography, hydrology, irrigation, mythology, history, barong migrations and temple connections. The following sections summarise these 'layers' of linkage. 


\section{Figure 3: The Wos Valley}

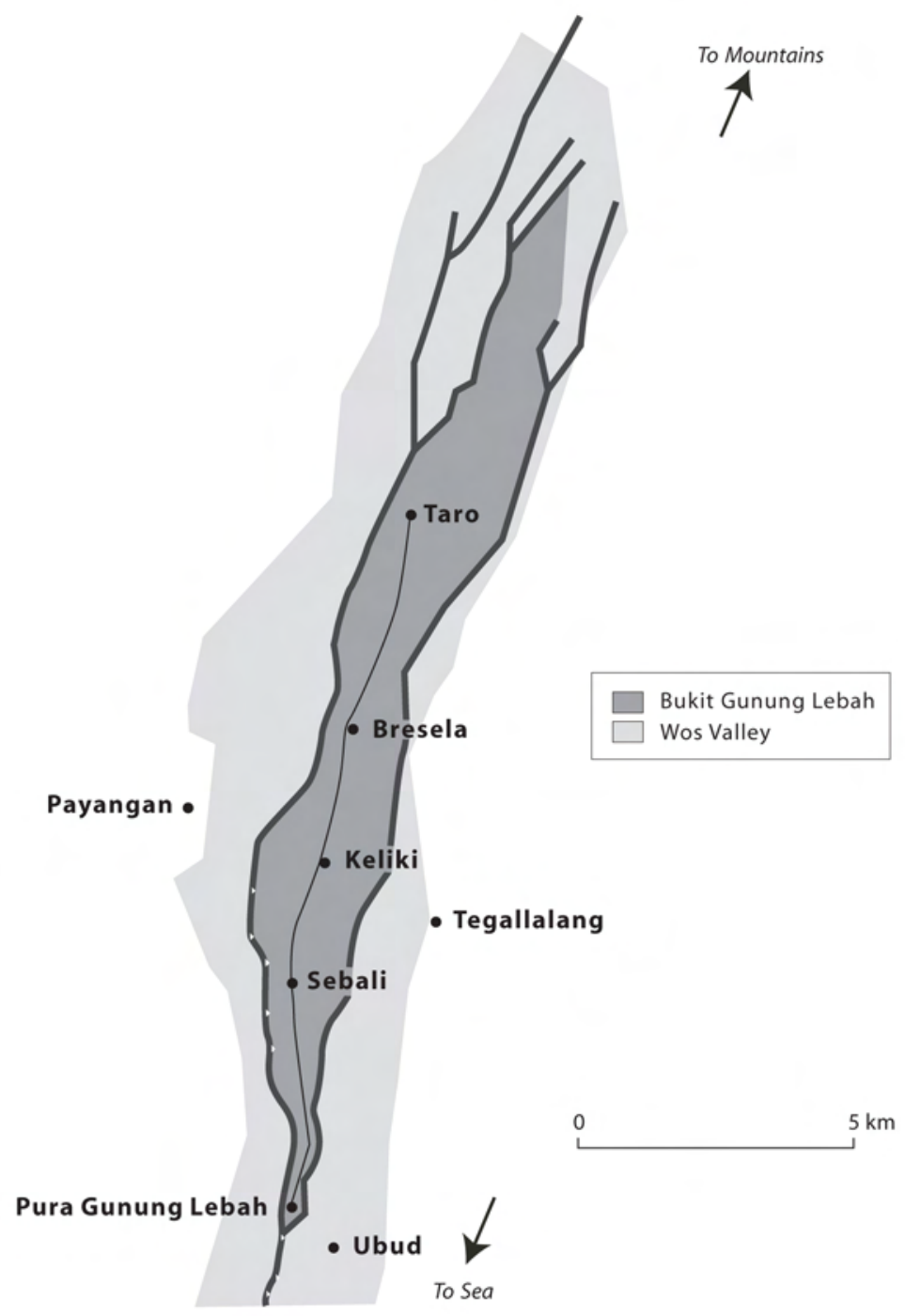

\section{Irrigation}

Pura Gunung Lebah sits on the lower end of a ridge (bukit). This narrow ridge, never more than two kilometres across, runs uphill, between two deep, forested ravines in which flow the east and west arms of the Wos, until it flattens out onto the plateau flanking the crater of Gunung Batur. On either side of this double valley run the parallel ridge roads through the major villages and court centres of Peliatan-Tegallalang-Pujung and Sayan-Kedewatan-Payangan. 
Figure 4: The Upper Wos Valley: irrigation

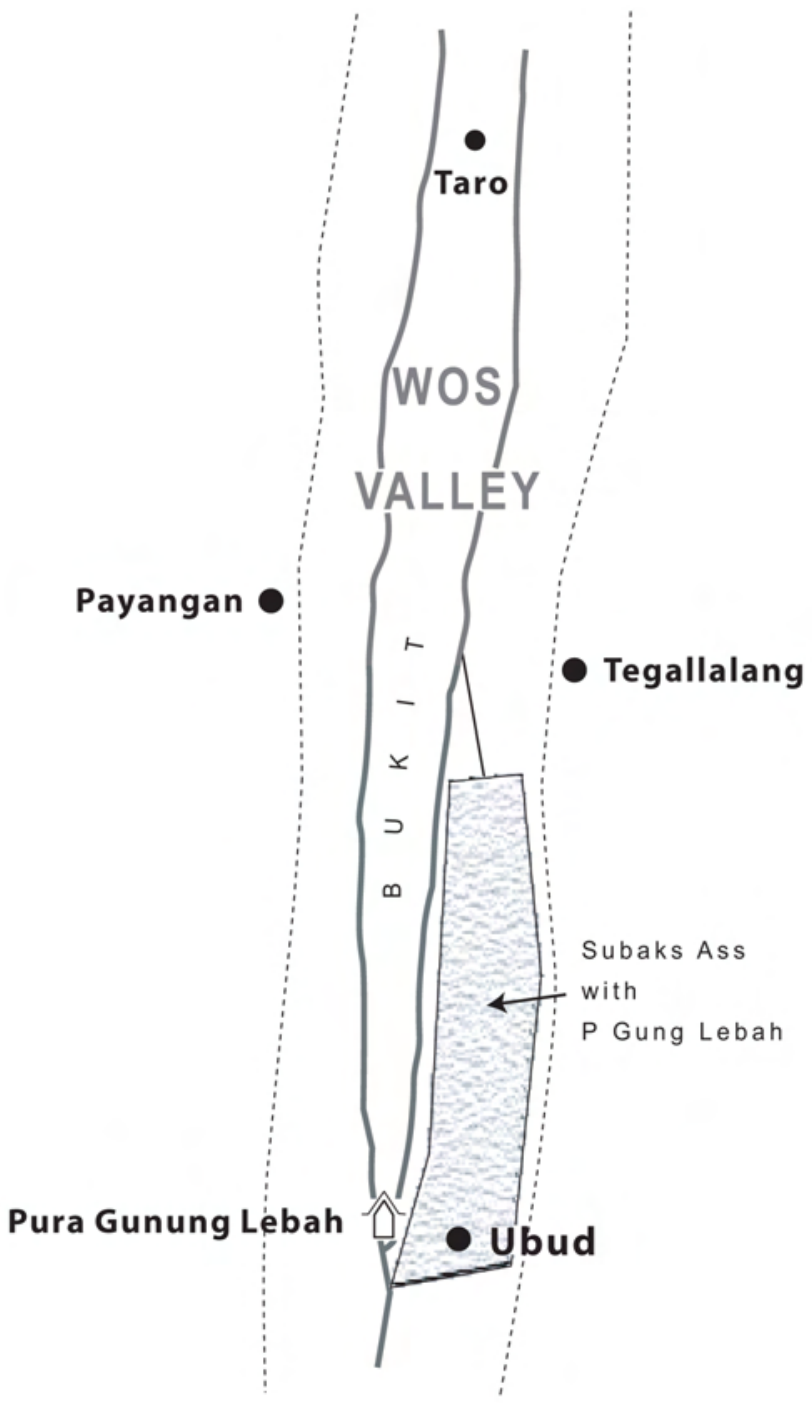

Along the central ridge are a series of villages strung along a narrow road. The gradient is gentle and easily traversed and the distances between settlements are generally no more than a kilometre. The intermediate sawah (irrigated rice fields) are traditionally worked by families of both, or even other, villages, and there are few obstacles to up-down-bukit travel. Irrigation and sawah ownership tend to cross village boundaries and collective maintenance and management of the irrigation system necessitates a degree of cooperation between upstream -downstream neighbours. 
Figure 5: The Upper Wos Valley: Rsi Markandeya's journey

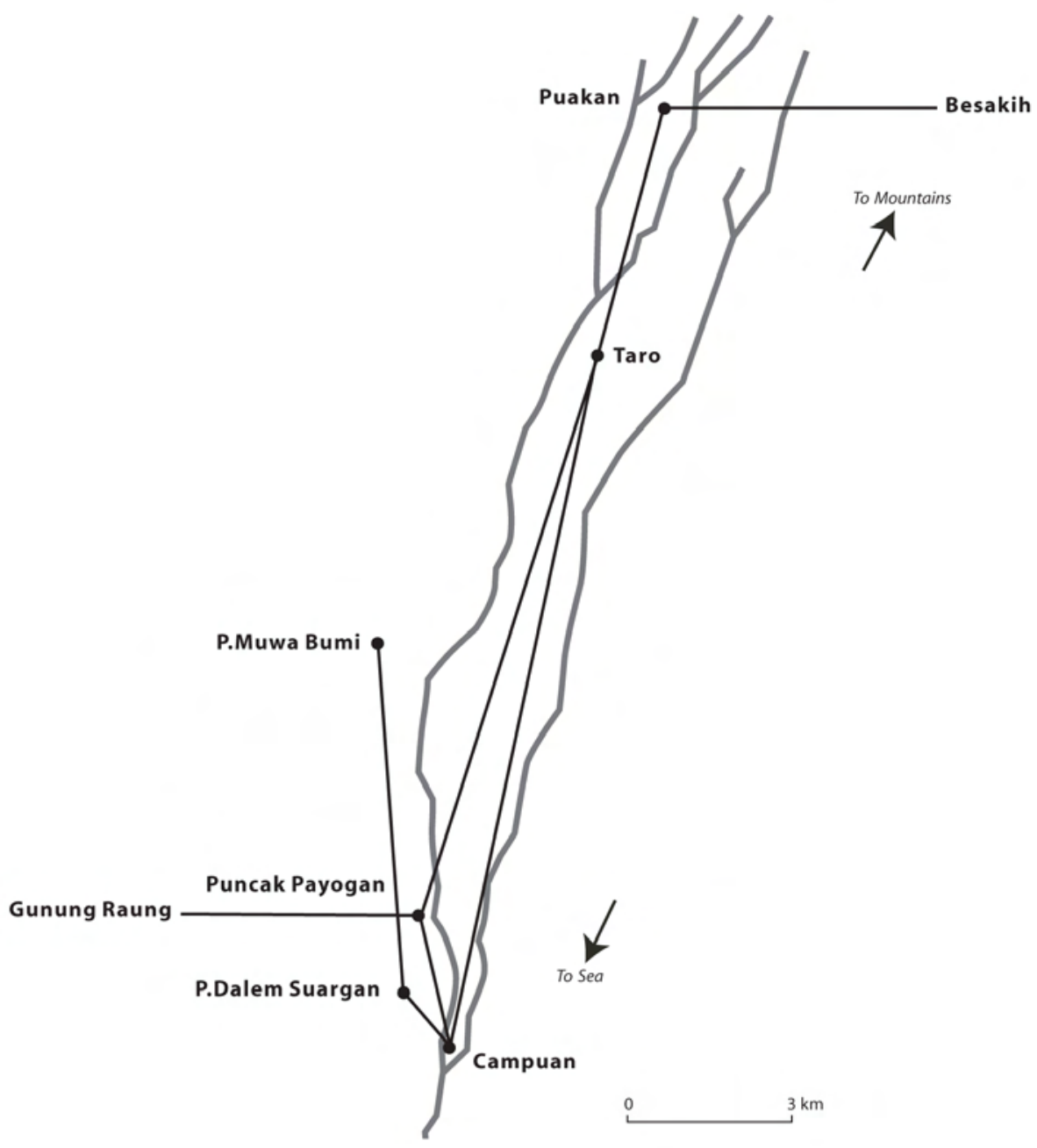

Balinese irrigation is gravity-fed and flows from mountain lakes and springs. Because of the depth of the river gorges, water is channelled from sources far upstream of the fields it irrigates and can be used only within the valley in which it originates. This basic hydrological form configures irrigation, like the land itself, into a set of long, narrow systems that depend on cooperation between upstream and downstream users of the system. ${ }^{17}$

Within the Wos Valley, the rice fields along the bukit from Bankiangsidem to above Taro are irrigated from dams on the two inner arms of the Wos. Although these subak are within the area associated with Pura Gunung Lebah, they do not relate to it as their pura masceti. Conversely, the primary congregation of the temple in its function as pura masceti are subak, which are physically located 
outside the bukit but draw their water from a dam on the Wos. Land and irrigation are separated ritually and the area served by Pura Gunung Lebah in its function as an irrigation temple does not correspond physically with the area with which it is connected in other ways.

\section{Rsi Markandeya}

Throughout the Wos Valley, the Markandeya story is trundled out routinely in response to questions about the foundation of local villages and temples. The details vary and village people frequently refer to Puri Ubud or to published versions for the 'complete' or 'correct' story. 18

Although not all the places mentioned in these stories are confined, even in the most parochial versions, to the bukit, the story serves to identify the poles of Campuan and Taro and an axis between them and to identify these with the foundations of Balinese civilisation. To its inhabitants, this area is known by such names as Ujung Taro, Bukit Taro, Gunung Taro, Gunung Raung or Bukit Gunung Lebah and is replete with material evidence of Rsi Markandeya's exploits, mostly in the form of temples.

\section{The Migratory Habits of Barong}

Barong, 'at once the most familiar and the most obscure' figures in Balinese tradition (Spies and de Zoete 1973: 93) are known to everyone but understood only in contradictory ways by relatively few people. ${ }^{19}$ They are essentially creatures of place, associated with desa and their territories, which they patrol seasonally to prevent the entry of unwanted influences. As Mead (1970) observed, they are subject also to a season of migration during which they might wander promiscuously performing as their will or habit takes them. They also practice a third, more regulated kind of migration: mutual visiting, along with other sacred objects (pretima), at temple ceremonies. It is through these visits that contemporary ritual links between villages in the Wos Valley are most readily traced.

For example, at the odalan of Pura Jemeng in Sebali, in addition to three barong from local temples, others are (usually) brought from Keliki, Lungsiakan, Ubud and Bentuyung. Likewise, reciprocally, the resident barong at Pura Jemeng attends odalan at the home temples of all these barong and at Pura Gunung Lebah. Keliki is immediately up-bukit of Sebali, with which it has close historical links. Some of these barong also travel, along with others from the area, to Pura Sabang Dahat, on the lonely plateau above Puakan. Every Manis Galungan, many barong, mostly from Bukit Taro/Gunung Lebah, present themselves at this temple and report to other local temples before making their own ways back down the bukit. ${ }^{20}$ For the month after Galungan, reciprocal visiting continues between barong in the area. 
Sharing the Earth, Dividing the Land

Figure 6: The Upper Wos Valley: barong migrations

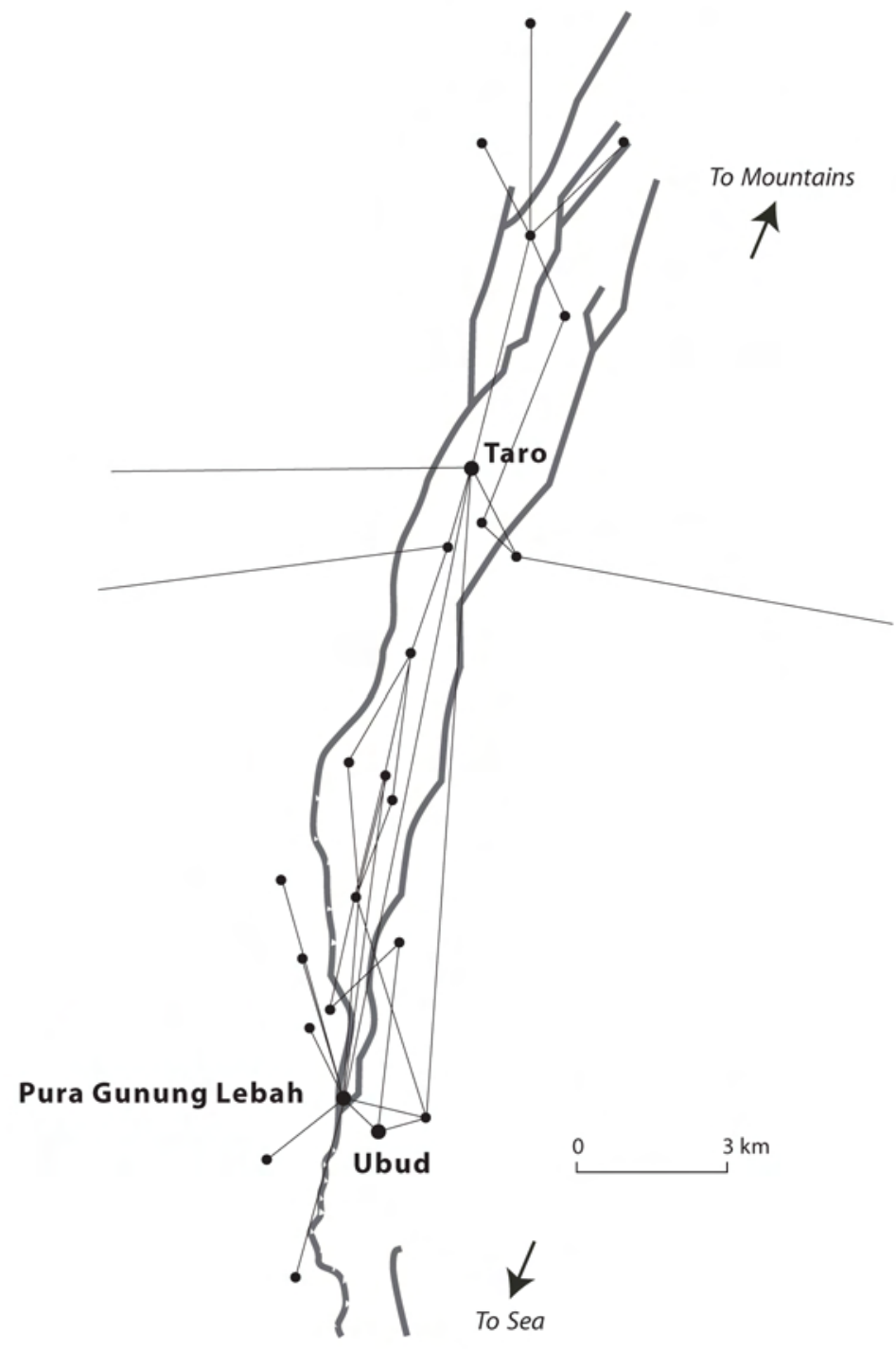

Most other desa have similar networks of related villages and temples which, can be traced by the travels of their barong. Taken together, the dominant pattern of connection is along the kaja-kelod axis within the bukit, but there are also some trans-bukit links to Ubud and others to apparently random temples elsewhere. 
Figure 7: The Upper Wos Valley: bale agung orientations

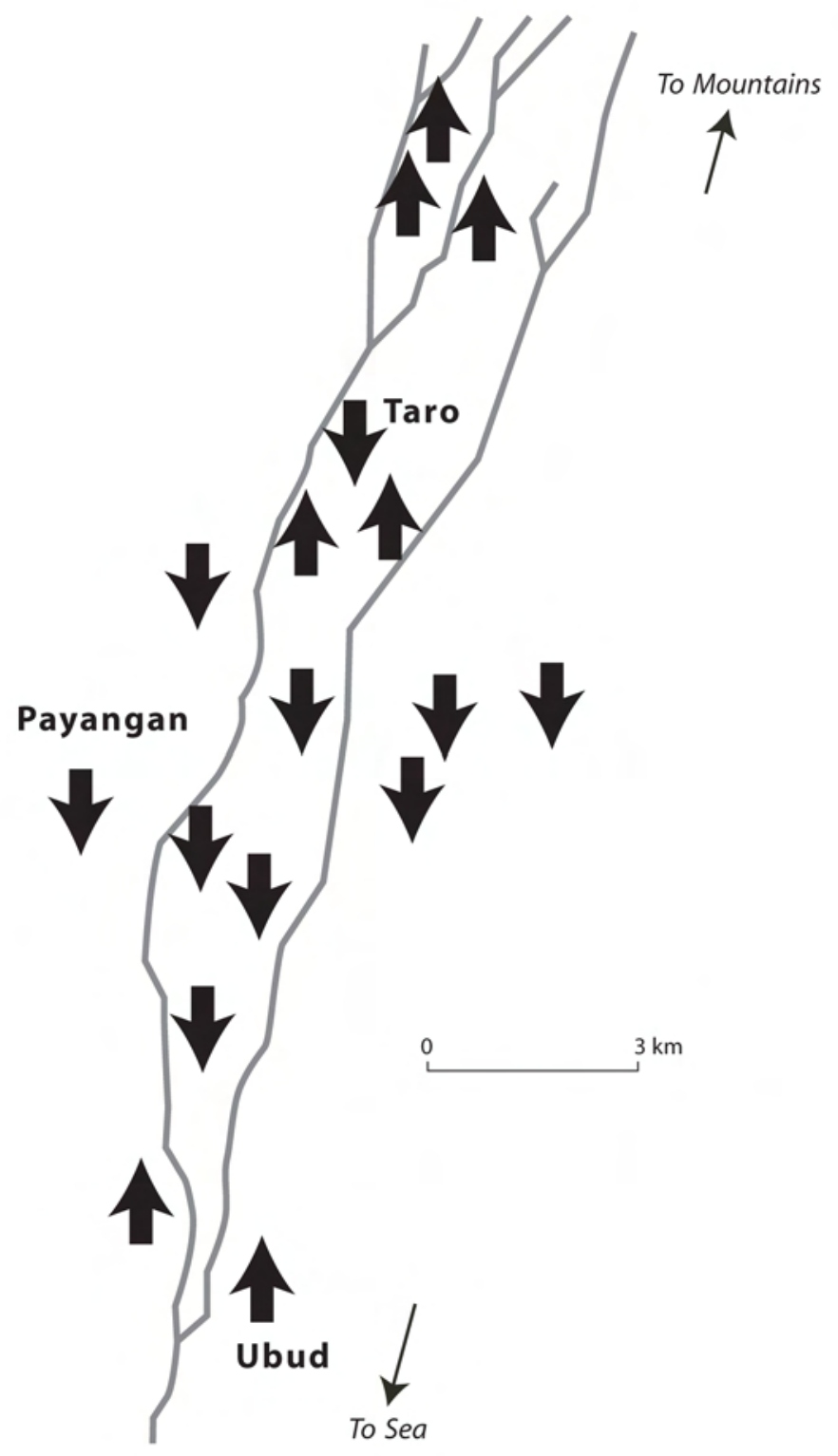

\section{Bale Agung and Reversals of Orientation}

A bale agung (lit: 'great pavilion') is a raised pavilion in which the gods associated with a village assemble. In old-style villages, it was oriented along the central kaja-kelod axis in the centre of the village and was large enough for living village 
members to occupy together with their deified ancestors at monthly meetings. ${ }^{21}$ In new-style villages, it is large enough only for the gods and is situated in the middle courtyard (jaba tengah) of one of the village temples. In either case, it is linear in form and oriented kaja-kelod. ${ }^{22}$ Furthermore, it is directional, having a head (ulu), which may consist of an enclosed timber cabinet containing sacred objects, a seat, or a (usually painted or carved) timber panel. The most important offerings are placed at this end and in old-style bale senior members of the village sit at this end. In the majority of bale, this head is oriented, like the heads of other entities of higher status or purity, kaja, uphill. 23

The bale agung that forms part of the Pura Agung Gunung Raung complex in Taro, widely believed to be the longest and the oldest in Bali, is oriented in the opposite direction, with its head downhill, towards the sea! So also are the bale agung of Sebali/Bankiangsidem, Keliki Kawan, Keliki/Yehtengah, Kelusa and Bresela. This is an extraordinary reversal of convention, affecting the majority of bale within the bukit, although there are significant exceptions. ${ }^{24}$ So, while within the area of Bukit Taro-Gunung Lebah there is a dominant pattern of reversal of normal orientation of bale agung there are also sufficient exceptions and anomalies to cast doubt on any easy generalisation.

Local explanations of this pattern of reversal are confusing but reflect a certain logical consistency. ${ }^{25}$ Bale agung in this area, associated with Rsi Markandeya and Gunung Raung, are oriented not to the central mountains but to Gunung Lebah, which is the pusat (BI: centre), puseh (navel, origin) or puncak (peak, summit) of this area. When I pointed out to local people that 'Gunung' Lebah seemed to me to be at the lowest rather than the highest point of the bukit, I was referred to the mystery contained in the name 'Gunung Lebah': the low mountain or the mountain at the bottom.

On what grounds can Gunung Lebah be described as a puncak? According to some, because Rsi Markandeya appeared first at Campuan and then travelled kaja along the bukit this was the pusat and therefore also the puncak. ${ }^{26}$ There is, however, sufficient uncertainty and contradiction in accounts of the direction of his travels that this explanation seems incomplete at best.

More philosophically sophisticated exegeses, by priests and princes, invoked the principle of the unity of high and low, mountain and sea, Brahma and Visnu. Just as the waters may be seen flowing from the mountains down to the sea, they also return, unseen to the mountain lakes (Schulte-Nordholt 1991: 157). The orientation to Gunung Lebah thus reflects the reversal at a niskala level of ordinary sekala orientation. ${ }^{27}$ A further variation of this explanation was that the location of Gunung Lebah is at the central point on the whole mountain-sea axis and was thus the pusat or puncak of the whole (inherently reversible) system. 
Figure 8: Upper Wos Valley: Puri Ubud patronage

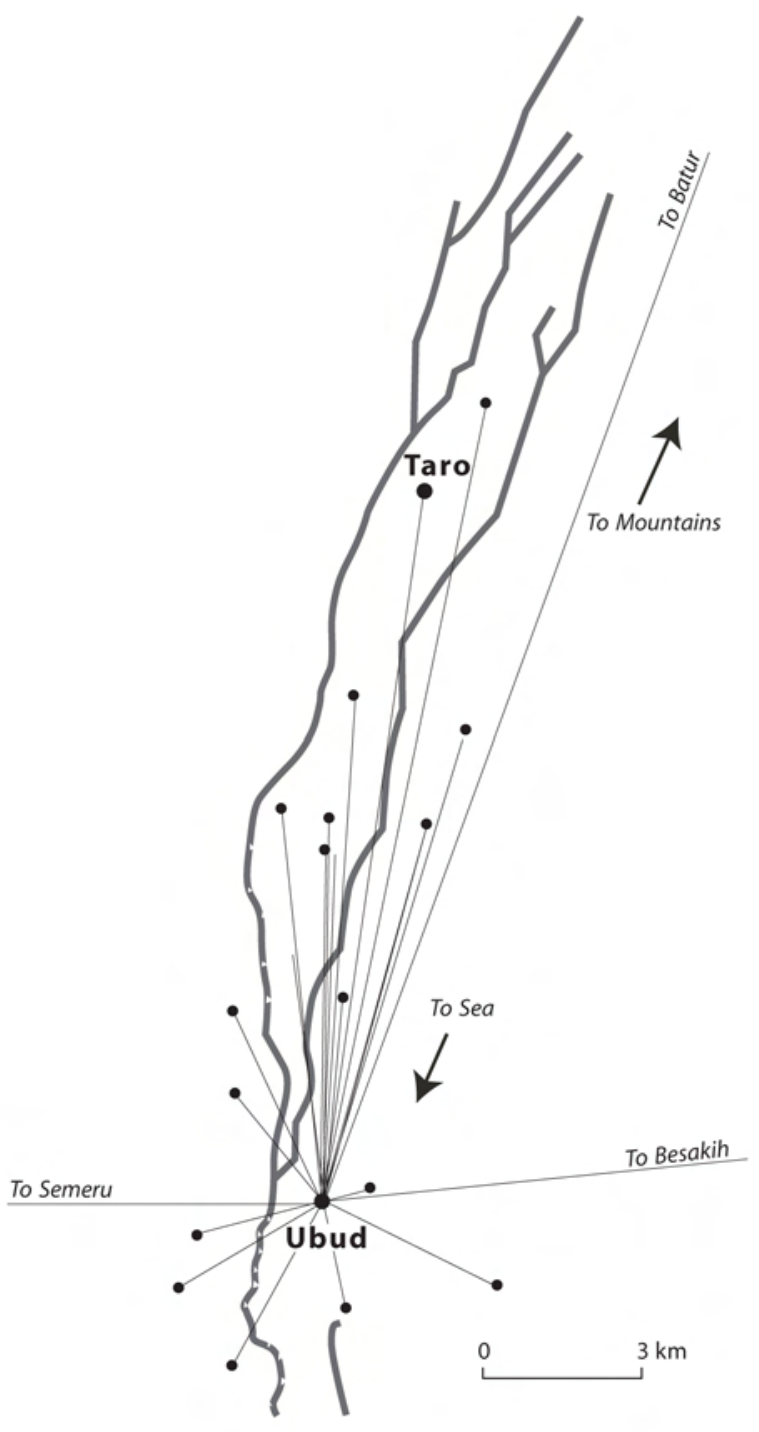

Logically unsatisfying as these explanations might be, the point in each case is clearly that within the boundaries of Bukit Gunung Lebah, ordinary sekala topography is in certain respects subordinate to a localised niskala topography of which Gunung Lebah is a peak or summit. 


\section{Puri Ubud}

Throughout my inquiries, wherever bale agung were oriented kelod, wherever Rsi Markandeya was said to have been, wherever barong were linked, and especially throughout Bukit Gunung Lebah, there was evidence of the patronage and influence of Puri Ubud. This involvement took forms such as renovation of temples, support of local dance/music groups, advising on matters of tradition and providing rationalised interpretations of local mythical history. In return, the puri were deferred to on matters of tradition and invited to ceremonies in local pura. They also called on such villages to provide ritual labour or performances at Ubud temples or puri.

Local people speak of this relationship as an appropriate continuation of long tradition. Members of the puri regard it as their hereditary obligation: leadership, guidance of the community and protection and sponsorship of traditional cultural forms. The geographical spread of this involvement does not, however, correspond with any precision to the area controlled by the puri in pre-colonial times.

Puri Ubud also assume a central position in the network through their controlling role at Pura Gunung Lebah. It is not uncommon for local puri to take over responsibility for pura mascet $i$ within their area of politico-ritual jurisdiction (Lansing 1991: 131). Pura Gunung Lebah is, like other irrigation temples, a visiting place (pasimpangan) of Pura Batur, whose principal deity has jurisdiction over all water flowing through this part of Bali (Lansing 1991: 74). Although the puri (and the local subak) have links with this temple, other aspects of the network described however do not extend directly to Batur.

\section{Networks and Layers}

Such are the more obvious dimensions or 'layers' of interconnection between places in this landscape. They are mutually connected by virtue of a degree of overlap, spatial and conceptual, hinging around the axis of Bukit Taro/Gunung Lebah. This overlap, however, is less than perfect and exceptions and anomalies abound.

It is perhaps timely at this point to remember two things. The first is that, as James Fox (1993: 23) reminds us, the 'symbolic orders' of Austronesian space tend to be 'multiple' and are 'constantly created and recreated' though ritual practice. The second is that these 'networks' and 'layers' are, unlike the mountain banua recorded by Reuter, not local categories of speech and thought, much less institutions of systematic practice, but abstractions created from my observations of a corpus of local practices and stories, which establish relationships between places and institutions. The analytical question would thus appear to be whether these systems and their correspondences are coincidence, figments of an overheated anthropological imagination, manifestations of normal Austronesian 
symbolic pluralism, residues of Austronesian banua or 19th-century negara, or whether they reflect an order of some other kind.

Knowledgeable local people with whom I discussed my work recognised the direction of my inquiries but were unable (or perhaps unwilling) to formulate it in any clearer terms. I sought therefore to 'explain' my findings by reference to some underlying order at a further level of abstraction. Neither Lansing's 'systems' of 'water temples' nor any other structural logics provided this. Every case has its own explanation, unique and sometimes seemingly quixotic. These local explanations are instructive: when I inquired about relationships between villages, temples or barong, I was frequently answered with vague reference to Rsi Markandeya or Gunung Lebah or simply the self-evident 'ada hubungan' (there is a relationship). If I pressed the matter harder, there was usually someone who could provide an explanation specific to the case in question. Such explanation inevitably took the form not of logical structural relationship but of a story relating specific mytho-historical causes: barong made from wood from the same tree, a king who had received divine inspiration at this spot and had founded a temple that the local village looked after on his behalf. Things are said (and seen) to be the way they are 'because' of the story of their origin. Likewise, the exceptions to the dominant pattern of reverse-oriented bale agung discussed above are all explained not by logical default to the status quo but by reference to their specific historical origins. This led me to look more seriously at the historical processes at work (and seen to be at work) in the area. ${ }^{28}$

\section{Negara and Banua}

What are known in the historical literature as 'kingdoms', to Balinese as kerajaan and to some writers (Geertz 1983; Schulte-Nordholt 1996) as negara, were indeed a form of trans-desa politico-ritual organisation, albeit imposed from the top down and fluid and unstable at the best of times. They were, however, based on an (at least implicit) ideology of 'ritual domains'. This ideology is re-packaged in Indic political-religious thought, embedded architecturally in the forms of centric mandala village plans and linguistically in terms such as jagat ('world/universe') and bhumi, but what gives such legitimating power to this ideology is the fact that it resonates with older Balinese ideas of what I call niskala landscape. These seem to me to be not unlike the ideas embedded in the banua of highland Bali: 'sacred landscapes inscribed by a continuing history of human action and re-inscribed through narrative and ritual performances' (Reuter, this volume). Let us consider briefly the history of Negara Ubud in this light.

\section{Negara Ubud}

In the orthodox history of Bali, Ubud was a minor puri, at best secondary to the eight subdued by the Dutch and subsequently immortalised as modern administrative districts (kabupaten). ${ }^{29}$ In fact, at the time of the Dutch takeover, 
the ruler (punggawa) of Ubud was arguably the most powerful person in this part of Bali (A. Agung 1991: 134; Mahaudiana 1968: 97; Vickers 1989: 75, 140). Together with his allies, he controlled a vast tract of land between the Rivers Ayung and Petanu, from the coast at Ketewel to near Taro in the mountains.

Puri Ubud's claim to this area was, and still is, made firstly on the basis of descent from the former kingdom of Sukawati, which, from the early 18th century held nominal jurisdiction over the entire land between the Ayung and Pakerisan rivers, from the sea to Mt Batur (G. Agung 1983; Sanggra 1971). This jurisdiction was based not on conquest or physical occupation, but on transactions with the invisible custodians of this territory: it was, in other words, essentially a niskala domain rather than a political one. ${ }^{30}$ Because of the subsequent dissolution of Sukawati and absorption of its scattered satellite puri into the emergent kingdom of Gianyar in the late 18th century, the Sukawati descendants had to wait more than a century and resort to warfare to reclaim their inheritance in political or sekala form.

This occurred in a confused series of rebellions within and wars between kingdoms towards the end of the 19th century. In the midst of this turmoil, the Prince of Ubud and his neighbouring relatives combined forces to take control of much of this territory in 1891 (A. Agung 1991; G. Agung 1983; Mahaudiana 1968: 82-85; Sanggra 1971). The details of the subsequent redistribution of land are not entirely clear but Ubud, as the strongest (if not senior) partner in the alliance, gained control of the western half of the Wos Valley from the sea to around Bresela. ${ }^{31}$ This formed the basis of an area over which Puri Ubud held power until Gianyar came under Dutch protection in 1900 and, even after this, a residue of political-economic and moral-spiritual authority, which is by no means defunct today.

The ruler of Ubud played an important role in the King of Gianyar's decision to place the kingdom under Dutch protection, and throughout the colonial period members of Puri Ubud successfully cultivated relationships of mutual benefit with the Dutch (Hilbery 1979; Schulte-Nordholt 1996: 200; Vickers 1989: 140). They also cultivated relationships with other foreigners, which were to provide the contacts, reputation and skills on which the tourist industry was subsequently built (MacRae 1992; Vickers 1989: 140-2). Although the relationship between puri and people remained close, with puri members assuming active roles in government (dinas) and customary (adat) institutions, internal tensions within the puri (Hilbery 1979: 12-15), followed by the political and economic instability of the years from 1940 until 1965 (Bagus 1991; Robinson 1988; Hilbery 1979: 2; Vickers 1989: 146-73), diverted the interest and resources of the puri away from matters of tradition, especially in areas remote from Ubud. By the time tourism began again in the late 1960s, Ubud was poor and divided and the 
puri's relationship with the further reaches of its former kingdom was at a low ebb.

Figure 9: Ubud territory in the late 19th century

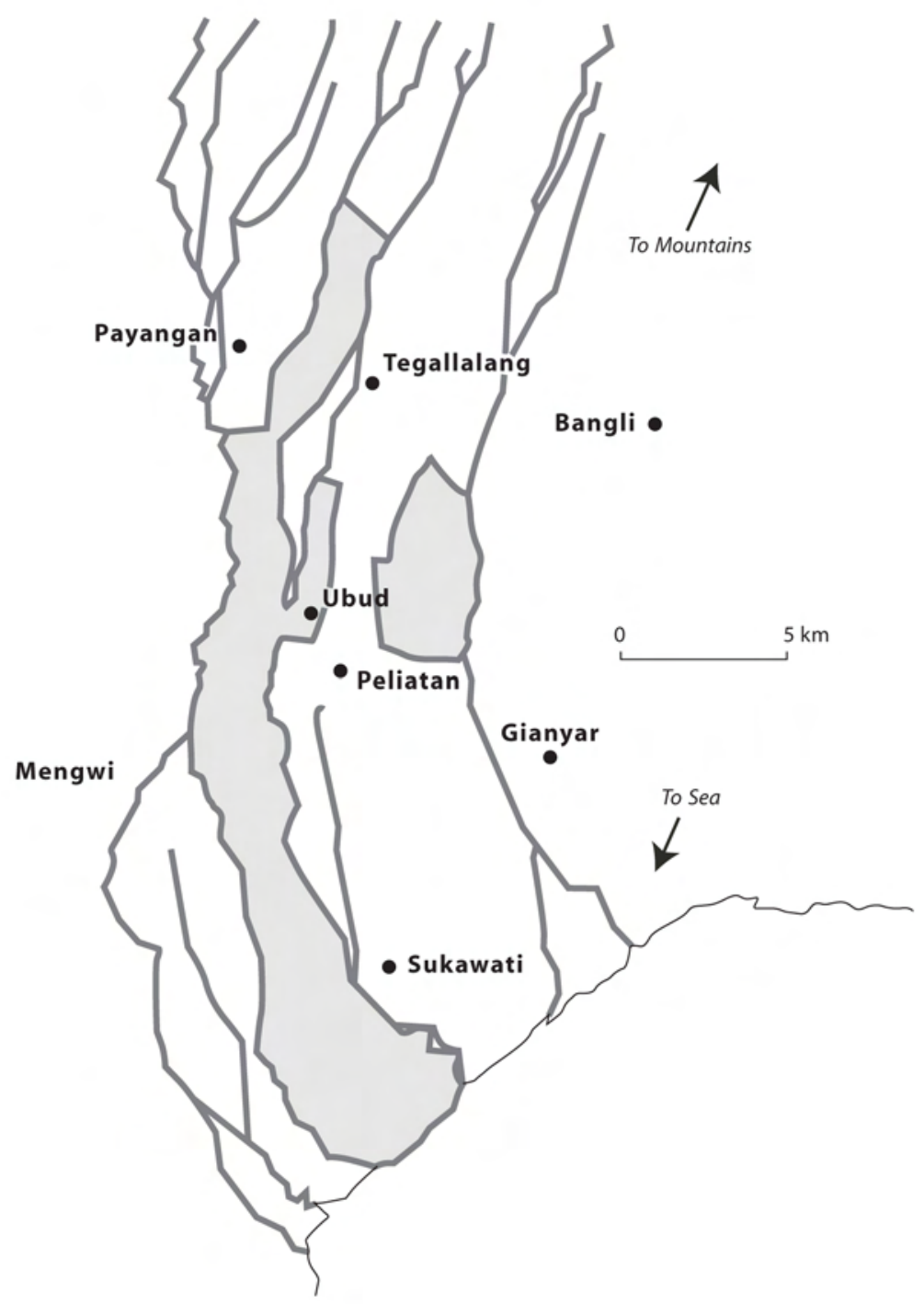

During the 1970s and '80s, as Ubud prospered through tourism, the puri prospered too through extensive sales of land and development of its own tourism interests. Unlike other puri which concentrated on politics and business (C. Geertz 1963: ch.4; Hanna 1976: 122-8), Puri Ubud sought also to re-establish 
their role as guides and guardians of local tradition as well as taking prominent positions in the local administration (MacRae 1999).

Outside Ubud, where such avenues were not open to them, especially in areas such as Bukit Gunung Lebah, which is part of another administrative district, Puri Ubud reverted to the old standby of royal patronage to reclaim their kingdom. During the 1960s, Ck. Agung Sukawati involved himself in the restoration of temples and pretima (sacred objects) all over Bali (Hilbery 1979). Upon his death, this mantle was taken up by his nephew, Ck. Agung Suyasa, who, since the late 1980s, has embarked on a program of sponsorship of ritual and culture around Ubud, up the Wos Valley and in other places. This program is based on restoration of temples, organising of and contributing to ceremonies, renovation of dance and music troupes and especially barong as well as researching and interpreting local history and tradition. Much of the evidence of niskala landscape and negara recorded above are in fact the fruits of this programme.

So while the history of Negara Ubud is at one level a conventionally politico-military one, it has at various crucial points been built and rebuilt on ideas of sacred landscape - successive political domains have been built on underlying assumptions of a ritual domain.

\section{The Network as a System of Knowledge}

It is the program of sponsorship by the puri that today draws together the diverse layers into what I have described as a network: a barong sponsored here, a temple restored there, a ceremony organised or an interpretation of the Rsi Markandeya story somewhere else. Some of these establish or reinforce direct links between villages and temples, all increase a sense of common 'shelter under the umbrella (payung)' of the puri.

This umbrella is, however, just one more image local people use to talk about an aspect (layer) of what I have been labouring to systematise into a network. What the puri are doing is systematising this same something but with an assurance that obviates any need to name it as such. Rather than a tangible network that can be plotted unambiguously on a map, what they are really working with is a set of ideas dispersed among a diverse corpus of practices and stories, a proto-theory of regional identity, a system of local knowledge integrated with the forms of ritual practice and narrative. It was the systematic nature of these ideas that people recognised when I spoke to them about my project and it is this basis of recognition also which provides the cultural material that the puri are recycling, developing and ordering. 


\section{Negara or Banua?}

The conclusions I have drawn previously from this evidence have tended to emphasise the way in which the puri has utilised this niskala landscape as a symbolic resource in a contemporary political economy dominated by tourism (MacRae 1997, 1998, 1999), namely by reconstructing, inventing (Hobsbawm and Ranger 1983) or imagining (Anderson 1991) a neo-negara, a new kingdom constructed in symbolic terms, through material practices of temple construction and ritual sponsorship. Seen through the lens of comparative Austronesian ethnography, however, it is instructive to consider the ways and extent to which this is built on foundations of appropriated local and inter-local organisation which predate and appear to exist independently of the puri and resonate with ideas more common to the Austronesian than the Indic world. ${ }^{32}$

Firstly, the idea that the landscape has, as well as its physical aspect, a subtle, inner magico-ritual aspect is common in India as well as throughout the Austronesian world. Some aspects of this landscape, however, take forms either more Indic or more Austronesian. Secondly, while sacred mountains are (literally) central to Indic sacred landscape, the primary level of spatial organisation in Bali - the linear uphill-downhill axis - corresponds directly to a well-documented Austronesian pattern as do the practices of orienting buildings and their component elements to this axis (Fox 1993: 14-15). The centric, mandala-type desa forms on the other hand, are unknown elsewhere in the Austronesian world and are in fact found in villages clearly dominated by puri of Hindu-Javanese descent. Thirdly, despite the absence of clear trans-desa levels of organisation such as the banua of the mountains, there is considerable evidence of an embryonic, residual or perhaps simply different form of inter-linkage between desa, articulated especially through temples. Fourthly, the programs of negara-building carried out by puri, while referring to aspects of Indic kingship, are based on mobilising relationships with and ideas about land, which are congruent with Austronesian ones in general and Bali Aga ones in particular.

\section{Twentieth-Century Transformations}

It was residues of some of the kerajaan of the 19th century that formed the basis of the considerable inequalities of land tenure that have continued in Bali to the present day. While some raja lost considerable amounts to the Dutch, others were able to retain and even consolidate their holdings (Mortimer 1972; Utrecht 1969). This inequality, combined with population increase, led to intensified competition for scarce productive land and facilitated systems of crop-sharing that favoured the interests of the landowners over those of their tenants. Dutch taxation policies placed considerable hardship on small farmers, which was intensified by the fall of commodity prices during the Great Depression. As a result, many farmers lost some or all of their land, further exacerbating existing inequalities. During the first decade of independence, in the 1950s, access to 
productive land was one of the burning political issues throughout Indonesia and was a major factor in the rise of the Communist Party (PKI), which lobbied strongly for a program of land reform. This was initiated in the early 1960s but landlords were able to retain significant amounts of land, by using strategies of obstruction and evasion (MacRae 1997: 383-5). The destruction of the PKI in the massacres of 1965-6 put an end to any further land reform program, although the original process has continued, slowly and incrementally, until the present (MacRae 1997: 386-7).

The primary piece of legislation (UUPA 1960) on which land reform was based also provides a set of legal tools for extricating land from the constraints of traditional collective tenure and enabling privatisation and alienation of land through a process of registration of title (sertipikat) in a manner essentially similar to Western models of private ownership.

Since then the economy has been transformed by tourism and associated export industries and the value of land has escalated exponentially (MacRae 1997: 70-8). People have come to think increasingly of land in terms of its exchange rather than use value, or ritual value. A generation ago it was considered highly inauspicious to sell rice fields, let alone convert them to non-agricultural use. Now owners of farm land regularly sell or convert land. The decline in incomes from farming has made this increasingly attractive, especially in major urban and tourist centres where often the least productive but strategically located land fetches astronomical prices. Others have lost their land as a result of compulsory acquisition for hotel construction. This commodification of land has led to new forms of wealth, but also to landlessness and poverty. The process has been aided and abetted by government programs providing the legal basis and moral encouragement to register land under individual, alienable title (sertipikat) - ostensibly to protect people from the depredations of former landlords, but simultaneously facilitating the sale and purchase of such land. Tanah pekarangan desa is also subject to registration in this way, but to date no one, in Ubud at least, has dared to sell such land. There are, however, partial exceptions and stories of it having happened elsewhere.

\section{Conclusion}

While the rituals of desa and bhumi linking people, land and gods continue on a scale not dreamt of by previous generations, the very land to which they refer is being steadily registered, subdivided, alienated and sold, often to foreigners. Austronesian ideas and practices of land belonging to the gods and of collective ritual responsibilities, transformed but reinforced by Indo-Javanese ideas and practices are now again being transformed but this time also eroded by the replacement of collective adat stewardship with private individualised ownership, commodification of the value of land and the transformation of the phenomenological experience of land by new technologies. Likewise the residual 
banua-like forms in this part of Bali are being progressively appropriated by processes of aristocratic control and harnessed to struggles for power in the tourism-dominated economy. While the land is being carved up; the ideologies embodied in ritual perpetuate the belief that the earth is still being shared.

\section{References}

Agung, A.A.G. 1989. Bali Pada Abad XIX. Yogyakarta: Gadjah Mada University Press.

Agung, G. 1981. 'Babad Dalem Sukawati.' Typewritten manuscript in latin script of Balinese, in possession of Puri Kaleran Sukawati.

Agung A. 1983. 'Sejarah Awal berdiri dan Berkembngnya puri Agung \& penataran Agung Tegallalang.' Photocopied typewritten Indonesian manuscript.

Anderson, B. 1991. Imagined Communities: Reflections on the origins and spread of nationalism. London: Verso.

Bagus, G.N. 1991. 'Bali in the 1950s: The role of the Pemuda Pejung in Balinese Political Process.' In H. Geertz (ed.), State and Society in Bali. Leiden: KITLV Press.

Bateson, G. 1970. 'An old temple and a new myth.' In J. Belo (ed.), Traditional Balinese Culture, New York: Columbia University Press.

Barnes, R.H. 1974. Kedang: a study of the collective thought of an eastern Indonesian people. Oxford: Clarendon.

Belo, J. 1953. Bali: Temple festival. Seattle and London, Washington: University of Washington Press.

Boon, J. 1977. The Anthropological Romance of Bali. Cambridge, London, New York, Melbourne: Cambridge University Press.

Budihardjo, E. 1986. Architectural Conservation in Bali. Yogyakarta: Gadjah Mada University Press.

Covarrubias, M. 1994. Island of Bali. New York: Knopf.

Creese, H. 1991. 'Balinese Babad as Historical Sources: a reinterpretation of the fall of Gelgel.' Bijdragen tot de Taal-, Land-, en Volkenkunde, 147. pp. 179-210.

Davies, P. 1991. 'The Historian in Bali.' Meanjin, 1 (1991). pp. 63-80.

Fox, J.J. (ed.) 1993. Inside Austronesian Houses: Perspectives on domestic designs for living. Canberra: Research School of Pacific and Asian Studies, The Australian National University. 
Fox, J.J. (ed.) 1997. The Poetic Power of Place: Comparative perspectives on Austronesian Ideas of Locality. Canberra: Research School of Pacific and Asian Studies, The Australian National University.

Geertz, C. 1959. 'Form and Variation in Balinese Village Structure.' American Anthropologist, 61. pp. 991-1012.

Geertz, C. 1980. Negara: the theatre state in nineteenth century Bali. Princeton: Princeton University Press.

Goris, R. 1969. 'The Decennial Festival in the Village of Selat.' In J. van Baal et al. (eds), Bali: Further Studies in Life, Thought and Ritual, The Hague: Van Hoeve.

Goris, R. 1984 (1960). 'The Religious Character of the village community.' In Swellengrebel (ed.), Bali: Studies in Life, Thought and Ritual, Dordrecht: Foris Publications.

Grader, C.J. 1969. 'Pura Meduwe Karang at Kubutumbuhan.' In J. van Baal et al. (eds), Bali: Further Studies in Life, Thought and Ritual, The Hague: Van Hoeve.

Guermonprez, J.F. 1990. 'On the Elusive Balinese Village: Hierarchy and values versus political models.' Review of Indonesian and Malaysian Affairs. 24. pp. 55-89.

Gunning, H. and A. van der Heiden. 1926. 'Het Petjataoe-en Anstveldenprobleem in Zuid-Bali.' Tijdschrift voor Indische Taal-, Land-en Volkenkunde, 66. pp. 329-94.

Hanna, W.A. 1976. Bali Profile. New York: American Universities Field Staff.

Hilbery, R. 1979. 'Reminiscences of a Balinese Prince.' S.E. Asia Paper No. 14. Honolulu: University of Hawai'i Press.

Hobart, A., U. Ramseyer and A. Leemann. 1996. The Peoples of Bali. Oxford, Cambridge (Mass.): Blackwell.

Hobart, M. 1979. 'A Balinese Village and its Field of Social Relations.' Unpublished PhD thesis, School of Oriental and African Studies, London.

Hobsbawm, E. and T. Ranger. 1983. The Invention of Tradition. Cambridge, New York: Cambridge University Press.

Howe, L. 1980. 'Pujung: The foundations of Balinese Culture.' Unpublished PhD thesis, University of Edinburgh, Edinburgh.

Howe, L. 1983. 'An Introduction to the cultural study of traditional Balinese Architecture.' Archipel, 26. pp. 137-58.

de Kat Angelino, P. 1921. 'De Robans en Parekans op Bali.' Kolonial Tijdschrift, 10. pp. $590-608$. 
Lansing, J.S. 1991. Priests and Programmers. Princeton: Princeton University Press.

MacRae, G.S. 1992. 'Tourism and Balinese Culture.' Unpublished M.Phil. thesis. University of Auckland, Auckland.

MacRae, G.S. 1997. 'Economy, Ritual and History in a Balinese Tourist Town.' Unpublished PhD thesis. University of Auckland, Auckland.

MacRae, G.S. 1999. 'Acting Global, Thinking Local in a Balinese Tourist Town.' In R. Rubinstein and L. Connor (eds), Staying Local in the Global Village: Bali in the Twentieth Century, Honolulu: University of Hawai'i Press.

MacRae, G.S. 2003. 'The Value of Land in Bali: Land-tenure, land reform and commodification.' In T.A. Reuter (ed.), Inequality, Crisis and Social Change in Indonesia: The muted worlds of Bali, London, New York: Routledge-Curzon Press.

Mahaudiana. 1968. Babad Manggis Gianyar. Gianyar: Thaman.

Mead, M. 1970. 'The Strolling Players in the Mountains of Bali.' In J. Belo (ed.), Traditional Balinese Culture, New York: Columbia University Press.

Mortimer, R.A. 1972. The Indonesian Communist Party and Land Reform 19591965. Melbourne: Centre for South-East Asian Studies, Monash University.

Reuter, T.A. 1998. 'The Banua of Pura Pucak Penulisan: A Ritual Domain in the Highlands of Bali.' Review of Indonesian and Malaysian Affairs, 32 (1). Pp. 55-109.

Reuter, T.A. 2002a. Custodians of the Sacred Mountains: Culture and society in the highlands of Bali. Honolulu: University of Hawai'i Press.

Reuter, T.A. 2002b. The House of Our Ancestors: Precedence and Dualism in Highland Balinese Society. Leiden: KITLV Press.

Robinson, G. 1995. The Dark Side of Paradise: Political violence in Bali. Ithaca, London: Cornell University Press.

Sanggra, M. 1971. Babad Timbul Sukawati. Sukawati: Yayasan Loka-Phala Budhaya (photocopied typewritten manuscript).

Schulte-Nordholt, H. 1991. 'Temple and Authority in South Bali, 1900-1980.' In H. Geertz (ed.), State and Society in Bali: historical, textual and anthropological approaches, Leiden: KITLV Press.

Schulte-Nordholt, H. 1996. The Spell of Power: a history of Balinese Politics 16501940. Leiden: KITLV Press.

Schwartz, H.J.E.F. 1906. 'Aanteekeningen Omtrent het Landschap Gianjar 1.' Tijdschrift voor het Binnenlands Bestuur, 1901-1906. pp. 166-89. 
Stuart-Fox, D. 2002. Pura Besakih: temple, religion and society in Bali. Leiden: KITLV Press.

Utrecht, E. 1969. 'Land Reform in Indonesia.' Bulletin of Indonesian Economic Studies 3. pp. 71-88.

Ubud. 1983. 'Monografi Kelurahan Ubud, tahun 1983-1984.' Typewritten manuscript. LKMD, Ubud.

UUPA. 1960. Undang-Undang No. 5 Tahun 1960 tentang Peraturan Dasar Pokokpokok Agraria. Government of the Republic of Indonesia.

Valeri, V. 1991. 'Afterword.' In J.S. Lansing, Priests and Programmers, Princeton: Princeton University Press.

Vickers, A. 1989. Bali: A paradise created. Ringwood: Penguin Books.

Warren, C. 1993. Adat and Dinas: Balinese communities in the Indonesian state. Oxford, Singapore, New York: Oxford University Press.

Waterson, R. 1997. The Living House: An anthropology of architecture in SouthEast Asia London: Thames and Hudson.

Wiener, M. 1995. Visible and Invisible Realms: power, magic and colonial conquest in Bali. Chicago, London: Chicago University Press.

de Zoete, B. and W. Spies. 1973. Dance and Drama in Bali. Kuala Lumpur: Oxford University Press.

\section{ENDNOTES}

${ }^{1}$ For a discussion of the political economy of land in south Bali, see MacRae (2003).

2 Translations are Balinese unless indicated as Indonesian (Bahasa Indonesia, BI).

3 The model presented here is based on understanding developed in the course of field research conducted in and around Ubud predominantly in 1993-94, 1996, and shorter visits in 1998 and 1999. This research is documented in detail in my PhD thesis (1997) and partially in previously published articles $(1999,2003)$.

4 Amongst the parade of great holy men, bearers of culture and religion from Java and beyond, who dominate early Balinese mytho-history, there is no mention (in English at least) of Markandeya until Howe (1980). He appears in old Indian texts and, according to Stuart-Fox (2002: 261) in old Javanese ones, but he has become widely known in Bali only in recent times. In the past couple of decades, a series of published versions of the story have appeared. Several of these refer to a 'Lontar Markandeya Purana', but Stuart-Fox was unable to locate any such original manuscript. One is said also to exist in the possession of Puri Ubud. In some cases, local oral versions have also been written and stored in private collections. For a more detailed discussion see MacRae (1997: 233).

5 For variations on this formulation, see Boon (1977: 94) and Geertz (1959).

6 The relationship is, as Guermonprez (1990) argues, more complex than this, and he offers a sophisticated, if contestable interpretation of it, but for the present purpose a 'social vs. ritual' is sufficient. For other interpretations, see Geertz (1959: 991), Stuart-Fox (2002: 31-4) and Warren (1993: 21-2).

7 The well-known kahyangan tiga (three temples) model, is an ideological construct of relatively recent invention. It entered Western discourse in 1935 (Goris 1960: 80-90) and has been recycled ever since with varying degrees of (mis) understanding and dogmatism in local, popular and academic forms. Empirically, however, it is - in this part of Bali at least - the exception rather than the rule (see also Stuart-Fox 2002: 23-4). 
8 This terminology, and the arrangements they refer to, varies somewhat in different parts of Bali (Stuart-Fox 2002: 43; Warren 1993: 39).

9 For descriptions of Balinese house yard layouts see Budihardjo (1986: 60-4), Covarrubias (1994: 90), Howe (1983) and MacRae (1997: 185-7).

10 Obvious examples of such desa include Ubud, Tegallalang and Payangan, but there are also less obvious ones such as Kedisan, Kebon and Sayan. For a detailed account of the establishment of such a 'royal centre', see Schulte-Nordholt (1991).

11 The landholding practices of Puri Ubud were something of an exception to this pattern, with the majority of land retained by the puri and sharecropped by local farmers, a system that has been of considerable commercial advantage to the puri in the tourism-driven inflation of land values during the late 20th century. For a detailed discussion of Ubud land tenure, see MacRae (2003).

12 See, for example, Covarrubias (1994), C. Geertz (1959), Guermonprez (1990), Hobart (1979), Schulte-Nordholt (1991) and Warren (1991).

13 Evidence presented here, unless referenced otherwise, is from my own fieldwork in Ubud and the areas immediately uphill during the years 1993-99.

14 Reuter (2002a) mentions a network of five villages around a temple, which is also called Pura Banua, located in the nearby village of Margatengah. Temples known as Pura Banua are not in fact uncommon in Bali. There is one in the Besakih complex (Stuart-Fox 2002: 400-1), and Grader (1969: 134-41) documented several in North Bali, which he believed to be associated primarily with dry-field agricultural ritual.

15 Puri means 'palace' or 'noble house' in the English multiple sense of a building, a family and a sociopolitical institution. Puri Ubud refers here to a cluster of some 40 households descended from the pre-colonial rulers of Ubud and who still occupy a prominent role in the public life of Ubud. I refer here to 'the puri' as if it were a single monolithic institution. In fact, this is far from the case and internal differences within the puri are an important part of the wider picture. For the purposes of this paper, however, I use it as a convenient shorthand for the collective interests of a cluster of related households descended from the original Puri Ubud.

16 James Fox (1993: 23), citing Roy Ellen and Clifford Sather, reminds us that the 'symbolic orders' of Austronesian space tend to be 'multiple' and 'constantly created and recreated in ritual.'

17 Liefrinck (1969) and Lansing (1991) describe this system in some detail.

18 Knowledge of the elements of the story is widespread in this area, especially among men of all ages. Confidence in retelling it and knowledge of details is surprisingly rare and is limited to a few, usually older men, not necessarily priests or leaders but with acknowledged expertise in matters of religion and history. These are precisely the people who tend to be least fluent in Bahasa Indonesia, so the fact that I initially worked entirely in this language probably left me with an impression of less knowledge than there actually is.

19 Barong are, in a material sense, giant puppets animated by men inside them. The most common forms represent animals, usually tigers or a vaguely leonine species of mythical beast known as ket(et), possibly descended from the dragons indigenous to the Far East (Belo 1949: 32-3) and related to similar creatures elsewhere in Indonesia. In niskala terms, they are a kind of deity resident periodically in this material body and/or the bodies of the men animating it. For a more detailed discussion, see MacRae (1997: 235-40).

20 Manis Galungan is an important day in the 210-day cycle of the Balinese calender and the beginning of the 35-day month during which most barong customarily make their travels.

21 The old/new terminology refers to differences first noted by Dutch scholars between the physical forms and social organisation of the Bali Aga villages found mostly in the mountains and those in the court-dominated lowland areas. In fact, many villages in the area discussed here display combinations of elements of the two ideal types. For recent discussions of this classification, see C. Geertz (1980), Guermonprez (1992), Lansing (1977: 217) and Warren (1991: 18).

22 There are around Bedulu and reportedly in Karangasem also a number of Bale Agung oriented east-west, the logic of which I have not yet investigated.

23 On the term ulu and its significance, see Howe (1980: 59).

24 The exceptions consist of bale within the bukit, which are oriented conventionally or split into sections oriented each way. In all cases there are specific historical reasons for the difference. The anomalies consist of bale outside the bukit, such as those at Payangan and in a group of villages east of 
Tegallalang, which are oriented downhill. The explanations of these are more complex and are beyond the scope of this essay.

25 These explanations were obtained from a wide range of local people in the villages concerned and were subsequently supplemented by the more impartial opinions of people of acknowledged expertise in Ubud and other places.

26 Michael Vischer has suggested (personal communication) similarities to materials from further east in the archipelago, where orientation to a 'point of origin' is common and cultural ideas are frequently expressed in the form of 'couplets' conjoining mutually contradictory concepts. See also Barnes (1974: 78-80) and Valeri (1991: 136-8) on this subject.

27 Pura Sang Hyang Tegal, a large temple dedicated to dry and wet agriculture and to Brahma and Wisnu, located between Taro and Puakan, and recently renovated by Puri Ubud, is also associated with this concept. A similar concept is embodied in the construction of mountain bale agung, said to represent 'divine unity and the passage ... through the circle of life, afterlife and rebirth' (Reuter 1996: 156).

28 The subject of 'history' in Bali is inherently problematic (see Bateson 1970 [1937]; Creese 1991; Davies 1991; Grader 1960: 163; Hobart 1979: 35; Schulte-Nordholt 1992; Vickers 1986, 1990; Wiener 1995: 76-96) and beyond the scope of this essay. I am concerned here less with verification of factual accuracy than with the use of history as a charter explaining and legitimating the present. The accounts I present here are assembled from the published material referred to in the text, most of which repeats, in more systematic form, oral accounts of people in and around Ubud.

29 I speak of orthodox history advisedly. History in Bali is no less contestable than anywhere else. There is, however, a broad consensus as to the overall outline, of which the various versions of the Babad Dalem are the primary source, aristocratic recitations the second and academic interpretations the third layer. These layers have become an orthodoxy enshrined in common knowledge, tourist guidebooks and academic publications.

30 For details of these transactions see MacRae (1997: 271-83.

31 Evidence of this division of territory can be found in Controleur Schwartz's report of 1900-the moment at which Gianyar came under Dutch protection. There is no reason to suppose that this represents any Dutch rearrangement. Local oral history, patterns of land ownership that survived even the land reform of 1961, and patterns of royal sponsorship of temples all confirm this picture.

32 It is perhaps appropriate to acknowledge, somewhat belatedly, that Thomas Reuter has long sought to remind me of how my material looked from the vantage point of the mountains of the Bali Aga and comparative Austronesian ethnology, and that Mark Mosko has likewise recognised this aspect of my material and urged me to develop it. 